\title{
CORRELATION BETWEEN HISTORY OF MATERNAL ANEMIA AND PREVALENCE OF 0-5 YEARS OLD STUNTING CHILDREN IN CILEMBU VILLAGE, SUMEDANG REGENCY, 2019
}

\author{
Batara Imanuel Sirait ${ }^{1}$ and Wiradi Suryanegara ${ }^{2}$ \\ ${ }^{1}$ Department of Obstetrics and Gynecology Medical Faculty, Universitas Kristen, Jakarta, Indonesia \\ ${ }^{2}$ Department of Medical Community Medical Faculty, Universitas Kristen, Jakarta, Indonesia
}
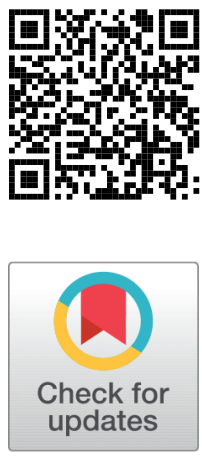

Received 6 April 2021

Accepted 21 April 2021

Published 30 April 2021

Corresponding Author

Batara Imanuel Sirait, batara.sirait

@uki.ac.id

DOI $10.29121 /$

granthaalayah.v9.i4.2021.3867

Funding: This research received no specific grant from any funding agency in the public, commercial, or not-for-profit sectors.

Copyright: (C) 2021 The Author(s). This is an open access article distributed under the terms of the Creative Commons Attribution License, which permits unrestricted use, distribution, and reproduction in any medium, provided the original author and source are credited.

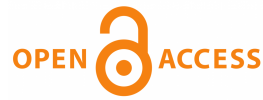

\section{ABSTRACT}

Stunting is a health problem among children in Indonesia, reaching 30,8\% and $29,9 \%$ on infants less than five years old and two years old. West Java prevalence of stunting is higher than $38,8 \%$ of the entire stunting population in Indonesia in 2018. Sumedang ranks second in districts with the highest prevalence of stunting in West Java, which is 19,4\%, according to Riskesdas in 2013. Stunting caused major problems are delayed mental development, lack of intellectual ability and long-term consequences of degenerative diseases. Anaemia is a public health problem that burdens developed and developing countries, especially adolescents and pregnant women. Risked data reaches $48.9 \%$ of anaemia incidence on pregnant women. Maternal anaemia can increase the prevalence of stunting. The purpose of this study to determine the Correlation between the History of Maternal Anemia and Prevalence of 0-5 Years Old Stunting Children in Cilembu Village, Sumedang Regency, January 2019 Period. This study used a cross-sectional analysis method, a sample of 61 consisted of stunting children aged 0-5 years in Columbus Village. Statistics is tested by Pearson correlation and also analysis of demographic data. The prevalence of maternal anaemia $50,8 \%$, and the highest category of stunting is very short (46\%). The results of Pearson's analysis found $(p=0.717>0.05)$ that do not have an association between the History of Maternal Anemia and the incidence of stunting aged 0-5 years old. There is no correlation between the History of Maternal Anemia and the incidence of stunting aged 0-5 years old in Cilembu Village, Sumedang Regency, January 2019 Period.

Keywords: Stunting, Anaemia, Maternal Anaemia

\section{INTRODUCTION}

Stunting is a public health problem of concern in Indonesia due to Indonesia's high incidence rate Sari et al. (2010); Schmidt et al. (2002); Torlesse et al. (2016). Accord- 
ing to Riskesdas, in 2018, stunting incidence reached $30.8 \%$ in toddlers and $29.9 \%$ in under two-year babies. It still has not reached the 2019 Regional Medium-Term Development Plan target for stunting, 28\%. The prevalence of stunting in West Java in 2018 amounted to more than $38.8 \%$ of Indonesia's entire stunting population. In 2013, Sumedang as the district was at second rank with the highest prevalence of stunting in West Java, namely 19.4\% Nainggolan and Siagian (2019); Sasongko et al. (2019). According to WHO (World Health Organization), a child is categorized as stunting if he/she has a height $<2$ SD (Standard Deviation) median WHO Child Growth Standards Stunting. Stunting is a condition in which a child has growth retardation caused by poor diet and recurrent infections. Stunting can cause delayed mental development, lack of intellectual abilities and long-term consequences, namely degenerative diseases Oriá et al. (2007); Ratna (2019). The complications of stunting can affect the economic productivity of a country because it is associated with the quality of human resources (HR) Dewey and Begum (2011); Hoddinott et al. (2013).

Anaemia is a public health problem that burdens developed and developing countries, especially adolescents and pregnant women. According to WHO data for 2011, $81.5 \%$ of women of reproductive age in the world have anaemia. According to Riskesdas in 2018 in Indonesia, the incidence of anaemia in pregnant women reached $48.9 \%$, including pregnant women aged $15-24$ years with anaemia reaching $84.6 \%$ of all anaemia incidents in pregnant women Diana et al. (2019); Lipoeto and Nindrea (2020); Warvadekar et al. (2018). According to WHO, anaemia is defined as a condition of haemoglobin levels $<12.0 \mathrm{~g} / \mathrm{dL}$ in women and $<13.0 \mathrm{~g} / \mathrm{dL}$ in men. Anaemia can be caused by various things such as folic acid deficiency, B12 deficiency, and iron deficiency. Iron deficiency anaemia is caused by massive iron deficiency in the body, which reduces erythropoiesis. The most significant impact caused by anaemia, especially in pregnant women, is to increase the risk of maternal and infant mortality, low birth weight (LBW), premature birth and affects the physical and mental development of children Bian et al. (2013); Iskandar et al. (2015); Kader and Perera (2014).

Anaemia in pregnant women can increase the risk of premature birth. In a study, pregnant women diagnosed with anaemia at week 13-24 of pregnancy had a 1.181.75 times greater risk of giving birth to preterm babies, low birth weight (LBW) and increased infant mortality. Preterm birth of infants is associated with an increased risk of stunting Christian et al. (2013); Lawn et al. (2014); Santos et al. (2009). The high incidence of stunting in the Sumedang Regency can be caused by anaemia in pregnant women. It can reduce the quality of community resources (HR) in a country, so this supports researchers to research the relationship of anaemia history during pregnancy to stunting at age 0-5 year in Cilembu Village, Sumedang Regency in 2019.

\section{RESEARCH METHOD}

The type of research used was an analytic observational study. The design used was cross-sectional to determine the relationship between anaemia history during preg- 
nancy and stunting children aged 0-5 years in Cilembu Village, Sumedang Regency in 2019. The time of the study was from 21 January 2019 - 8 February 2019. This research was conducted in Cilembu Village, Sumedang Regency. The sample was taken using the total sampling technique with a total population of 81 children, while the number of samples in the study was 81 children who met the inclusion criteria. The data collected is in the form of primary and secondary data. Primary data were obtained directly by researchers from respondents who were collected regarding the characteristics of mothers and characteristics of children. History of anaemia during pregnancy using Kartu Menuju Sehat. The collected data is then analyzed by univariate analysis to provide an overview of the characteristics of each variable studied and bivariate analysis to prove whether or not there is a relationship between dependent and independent variables using the SPSS (statistical package for the social science) application with the Pearson correlation test.

\section{RESULT AND DISCUSSION}

This research was conducted on a sample of children aged 0-5 years in January 2019 in Cilembu Village, Sumedang Regency, with a sample size of 61 people because

there are exclusion criteria, namely, one person moved domicile, and 19 people did not meet the incluion criteria. Then from the research results obtained the following data.

\begin{tabular}{|c|c|c|}
\hline BW & Number & $\%$ \\
\hline Short & 15 & $24,6 \%$ \\
\hline Very short & 46 & $75,4 \%$ \\
\hline Total & 61 & $100 \%$ \\
\hline
\end{tabular}

Of the total 61 samples, based on the category of children with very short stunting, as many as 46 samples (75.4\%), while the children with stunting were 15 samples (24.6\%).

\begin{tabular}{lcc}
$\begin{array}{l}\text { Table } 2 \\
\text { teristics } \\
\text { Weight }\end{array}$ & \multicolumn{2}{c}{ Sample Charac- } \\
Based on & Birth \\
& & \\
\hline BW & Number & $\%$ \\
\hline Normal & 46 & $75,4 \%$ \\
\hline Low & 15 & $24,6 \%$ \\
\hline Total & 61 & $100 \%$ \\
\hline
\end{tabular}

Of the total 61 samples, based on the category of children with very short stunting, as many as 46 samples (75.4\%), while the children with stunting were 15 samples 
(24.6\%).

\begin{tabular}{|c|c|c|c|}
\hline Age group & Age Category & Number & $\%$ \\
\hline $12-16$ & Early adolescence & 4 & $6,6 \%$ \\
\hline $17-25$ & Late teens & 33 & $54,1 \%$ \\
\hline $26-35$ & Early adulthood & 19 & $31,1 \%$ \\
\hline $35-45$ & Late adulthood & 5 & $8.2 \% \%$ \\
\hline Total & & 61 & $100 \%$ \\
\hline
\end{tabular}

Characteristics of the age when pregnant women with stunting children in the village of Cilembu mainly were in the 17-year age group. Namely, 33 samples (54.1\%). The age group 12-16 years has the lowest age group, namely four samples (6.6\%). The 26-35-year age group is in the second-largest position, namely 19 samples (31.1\%). The 35-45-year age group only has a difference of 1 sample with the 1216-year age group, namely five samples (8.2\%).

\begin{tabular}{lcc}
\hline $\begin{array}{l}\text { Table } 4 \text { Sample Characteristics Based } \\
\text { on Education }\end{array}$ \\
\hline Education & Number & $\%$ \\
\hline Primary & 33 & $54,1 \%$ \\
\hline Junior High School & 17 & $27,9 \%$ \\
\hline Senior High School & 11 & $18 \%$ \\
\hline Total & 61 & $100 \%$ \\
\hline
\end{tabular}

Of the total sample, the most current education level is SD, with 33 samples (54.1\%). The latest high school education has the lowest education level, namely 11 samples (18\%), the last education is 17 samples $(27.9 \%)$.

\begin{tabular}{ccc}
$\begin{array}{l}\text { Table } 5 \\
\text { Sample Characteristics } \\
\text { by Occupation }\end{array}$ \\
\hline Profession & Number & $\%$ \\
\hline Driver & 6 & $9,8 \%$ \\
Employees & 10 & $16,4 \%$ \\
entrepreneur & 19 & $31,1 \%$ \\
\hline Labor & 20 & $32,8 \%$ \\
Traders & 6 & $9,8 \%$ \\
Total & 61 & $100 \%$ \\
\hline
\end{tabular}

Based on the job characteristics, most are workers, as many as 20 samples (32.8\%). The occupation of drivers and traders has the same percentage, namely as many as six samples (9.8\%). Entrepreneurs occupy the 2nd most occupational 
characteristics, namely as much as $31.1 \%$.

\begin{tabular}{lccc}
\hline \multicolumn{4}{l}{ Table 6} \\
based on Upper Arm Circumference \\
\hline LILA & Nutritional Status & Number & $\%$ \\
\hline$<23$ & Less & 13 & $21,3 \%$ \\
$\geq 23$ & Good & 48 & $78,7 \%$ \\
\hline Total & & 61 & $100 \%$ \\
\hline
\end{tabular}

Of the 61 samples, 13 samples $(21.3 \%)$ of mothers with stunted children had low nutritional status during pregnancy. The nutritional status mentioned is based on the mother's LILA at the time of pregnancy.

\begin{tabular}{|c|c|c|}
\hline \multicolumn{3}{|c|}{$\begin{array}{l}\text { Table } 7 \text { Distribution of Anemia } \\
\text { Prevalence }\end{array}$} \\
\hline BW & Number & $\%$ \\
\hline Anaemia & 31 & $50,8 \%$ \\
\hline Not anaemia & 30 & $49,2 \%$ \\
\hline Total & 61 & $100 \%$ \\
\hline
\end{tabular}

Of the total 61 samples, based on the category of mothers with anaemia, there were 31 samples (50.8\%), while 30 samples (49.2\%) had no anaemia.

\begin{tabular}{|c|c|}
\hline $\begin{array}{l}\text { Table } 8 \\
\text { History } \\
\text { Pregnant } \\
\text { Incidenc }\end{array}$ & $\begin{array}{l}\text { Relationship } \\
\text { f Anemia in } \\
\text { Women and } \\
\text { of Stunting }\end{array}$ \\
\hline & Sig (2-tailed) \\
\hline Anaemia & 0,717 \\
\hline Stunting & 0,717 \\
\hline
\end{tabular}

In the Chi-Square test, it was conducted between anaemia during pregnancy and the incidence of stunting. The instrument is said to be related if the p-value $<0.05$. The analysis showed no relationship between anaemia in pregnancy and the stunting incidence with a value of $\mathrm{p}=0.717$.

\section{CONCLUSION}

The Pearson analysis results $(p=0.717>0.05)$ showed no relationship between anaemia in pregnancy and the incidence of stunting in children aged 0-5 years. Based on this study, it can be concluded that there is no relationship between anaemia in pregnancy and the incidence of stunting in children aged 0-5 years. 


\section{REFERENCES}

Bian, Y., Zhang, Z., Liu, Q., Wu, D., \& Wang, S. (2013). Maternal risk factors for low birth weight for term births in a developed region in China: a hospital-based study of 55,633 pregnancies. Journal of biomedical research, 27(1), 14-14.

Christian, P., Lee, S. E., Angel, M. D., Adair, L. S., Arifeen, S. E., Ashorn, P., Black, .., \& E, R. (2013). Risk of childhood undernutrition related to small-for-gestational age and preterm birth in low-and middle-income countries. International journal of epidemiology, 42(5), 1340-1355.

Dewey, K. G., \& Begum, K. (2011). Long-term consequences of stunting in early life. Maternal \& Child Nutrition, 7, 5-18. Retrieved from https://dx.doi.org/10.1111/j.1740-8709.2011 .00349.x 10.1111/j.1740-8709.2011.00349.x

Diana, R., Khomsan, A., Anwar, F., Christianti, D. F., Kusuma, R., \& Rachmayanti, R. D. (2019). Dietary Quantity and Diversity among Anemic Pregnant Women in Madura Island, Indonesia. Journal of Nutrition and Metabolism, 2019, 1-7. Retrieved from https:// dx.doi.org/10.1155/2019/2647230 10.1155/2019/2647230

Hoddinott, J., Alderman, H., Behrman, J. R., Haddad, L., \& Horton, S. (2013). The economic rationale for investing in stunting reduction. Maternal \& Child Nutrition, 9, 69-82. Retrieved from https://dx.doi.org/10.1111/mcn.12080 10.1111/mcn.12080

Iskandar, I., Hadju, V., Ad, S. A., \& Natsir, R. (2015). Effect of Moringa oleifera leaf extracts supplementation in preventing maternal anemia and low-birth-weight. International Journal of Scientific and Research Publications, 5(2), 1-3.

Kader, M., \& Perera, N. P. (2014). Socio-economic and nutritional determinants of low birth weight in India. North American Journal of Medical Sciences, 6(7), 302-302. Retrieved from https://dx.doi.org/10.4103/1947-2714.136902 10.4103/1947-2714.136902

Lawn, J. E., Blencowe, H., Oza, S., You, D., Lee, A. C., Waiswa, P., Lalli, M., Bhutta, Z., Barros, A. J., Christian, P., Mathers, C., \& Cousens, S. N. (2014). Every Newborn: progress, priorities, and potential beyond survival. The Lancet, 384(9938), 189-205. Retrieved from https://dx.doi.org/10.1016/s0140-6736(14)60496-7 10.1016/s0140 -6736(14)60496-7

Lipoeto, N. I., \& Nindrea, R. D. (2020). Nutritional contributors to maternal anemia in Indonesia: Chronic energy deficiency and micronutrients. Asia Pacific Journal of Clinical Nutrition, 29-29.

Nainggolan, S., \& Siagian, F. E. (2019). The prevalence of anemia in pregnant women in the 10 priority villages for stunting control in Sumedang district, West Java: a community-based survey. International Journal of Community Medicine And Public Health, 6(9), 3760-3760. Retrieved from https://dx.doi.org/10.18203/2394-6040 .ijcmph20193966 10.18203/2394-6040.ijcmph20193966

Oriá, R. B., Patrick, P. D., Blackman, J. A., Lima, A. A., \& Guerrant, R. L. (2007). Role of apolipoprotein E4 in protecting children against early childhood diarrhea outcomes and implications for later development. Medical Hypotheses, 68(5), 10991107. Retrieved from https://dx.doi.org/10.1016/j.mehy.2006.09.036 10.1016/j mehy.2006.09.036

Ratna, D. J. (2019). Factors Related to Stunting in Toddlers. 1st International Conference on Science, 190-193.

Santos, I. S., Matijasevich, A., Domingues, M. R., Barros, A. J., Victora, C. G., \& Barros, F. C. (2009). Late preterm birth is a risk factor for growth faltering in early childhood: a cohort study. BMC Pediatrics, 9(1), 1-8. Retrieved from https://dx.doi.org/10.1186/ 
1471-2431-9-71 10.1186/1471-2431-9-71

Sari, M., de Pee, S., Bloem, M. W., Sun, K., Thorne-Lyman, A. L., Moench-Pfanner, R., Akhter, N., Kraemer, K., \& Semba, R. D. (2010). Higher Household Expenditure on Animal-Source and Nongrain Foods Lowers the Risk of Stunting among Children 0-59 Months Old in Indonesia: Implications of Rising Food Prices. The Journal of Nutrition, 140(1), 195S-200S. Retrieved from https://dx.doi.org/10.3945/jn.109.110858 10.3945/jn .109 .110858

Sasongko, E. P. S., Ariyanto, E. F., Indraswari, N., Rachmi, C. N., \& Alisjahbana, A. (2019). Determinants of adolescent shortness in Tanjungsari. Asia Pacific journal of clinical nutrition, 28.

Schmidt, M. K., Muslimatun, S., West, C. E., Schultink, W., Gross, R., \& Hautvast, J. G. A. J. (2002). Nutritional Status and Linear Growth of Indonesian Infants in West Java Are Determined More by Prenatal Environment than by Postnatal Factors. The Journal of Nutrition, 132(8), 2202-2207. Retrieved from https://dx.doi.org/10.1093/jn/132.8.2202 $10.1093 / j n / 132.8 .2202$

Torlesse, H., Cronin, A. A., Sebayang, S. K., \& Nandy, R. (2016). Determinants of stunting in Indonesian children: evidence from a cross-sectional survey indicate a prominent role for the water, sanitation and hygiene sector in stunting reduction. BMC Public Health, 16(1), 1-11. Retrieved from https://dx.doi.org/10.1186/s12889-016-3339-8 10.1186/s12889-016-3339-8

Warvadekar, K., Reddy, J. C., Sharma, S., Dearden, K. A., \& Raut, M. K. (2018). Sociodemographic and economic determinants of adherence to iron intake among pregnant women in selected low and lower middle income countries in Asia: insights from a cross-country analyses of global demographic and health surveys. International Journal of Community Medicine And Public Health, 5(4), 1552-1552. Retrieved from https://dx.doi.org/10.18203/2394-6040.ijcmph20181234 10.18203/ 2394-6040.ijcmph20181234 